\title{
Organisational factors in the development and implementation of sustainable urban design: a preliminary assessment of innovation within a statutory urban land development agency
}

\author{
G. Binder \& T. Dalton \\ AHURI/NATSEM Research Centre, RMIT University, Melbourne, \\ Australia
}

\begin{abstract}
In Australia master-planned communities (MPC's) form a significant part of the outer suburban housing market. Recently developers have started to engage with the issue of Sustainable Urban Design (SUD). MPC's at the very least feature extensive on-site storm-water management. The Victorian State Government has developed an extensive urban planning policy for managing Melbourne's future growth that promotes sustainable urban design. The government statutory urban land development business, VicUrban, is charged with delivering this policy and is planning an 8000 home MPC, Aurora, which will feature extensive SUD principles. VicUrban is developing its Sustainability Charter to use in planning, implementing and evaluating its projects. The charter features a TBL framework as well as a focus on affordability and New Urbanism. The draft Sustainability Charter uses a scoring assessment framework for encouraging change. For example, points are awarded for desired features, like using materials with a low embodied energy, and penalties apply if items that have been discriminated against are used, for example using rainforest timbers. This paper starts to explore the organisational mechanisms that are being utilised by VicUrban to develop and implement SUD at Aurora.

Keywords: urban design, government business, scoring assessment, developers, sustainability, performance planning.
\end{abstract}




\section{Introduction}

This paper describes and assesses the work of VicUrban, the Victorian (Australia) Government's land development agency, in pursuing a sustainability objective through their land development program of acquiring, developing, and selling land on the fringe of metropolitan Melbourne. By early 2005 the process for guiding the design and development of VicUrban projects was made explicit in the VicUrban Sustainability Charter which uses five measures for assessing projects: commercial success; community wellbeing; environment; urban design excellence; and housing affordability. It is also aimed at encouraging an industry-wide approach to 'sustainability'. However, the way in which the charter might be influencing other developers is not considered in this paper.

The paper proceeds to describe and assess the VicUrban pursuit of the 'sustainability' objective in three sections. While there are three policy problems that VicUrban is seeking to address when it speaks of 'sustainability', the decline in housing affordability; the provision of services to new suburban areas; and reducing the environmental impact of low density suburban development, the confines of this paper only provide for the discussion of the third policy area.

Second, the draft VicUrban Sustainability Charter is discussed. It represents an innovation in what can be described as 'performance planning' guided by a type of 'triple bottom line' accounting where the performance of VicUrban project proposals are assessed against declared objectives. The objectives, the performance measures and the means used to assess projects are reviewed.

Third, an initial assessment of VicUrban performance against the draft Sustainability Charter measures is presented. Against the background of the policy problem discussed in the first section the question is posed 'What is the contribution that a government owned development agency can make to increase the long term sustainability of outer suburban metropolitan development?

\section{Policy problems}

A characteristic of many government agencies involved with developing and implementing metropolitan strategies is the use of the word 'sustainability'. As Gleeson et al [1] note, 'sustainability discourses form a policy arena that sprawls over multiple jurisdictions of departments, agencies and portfolios' (p. 250). For VicUrban the word is central in its claim that it is addressing environmental, social and economic issues. The VicUrban annual reports present the following formulation [2]:

Sustainability is the core principle underlying VicUrban's development approach. VicUrban uses the term holistically to include: respecting the environment; design excellence; community wellbeing; housing affordability; and commercial success. (p. 3)

When viewed historically the development of this wrap-around term has centred on three distinct challenges. They are decline in housing affordability; the provision of services to new suburban areas; and reducing the environmental impact of low density suburban development, but we confine our discussion to the last challenge - environmental impact. 


\subsection{Environmental impact of low density suburban development}

Urban land commissions date back to the 1970s. They were the result of the Federal government intervening in the urban land markets controlled by the states. This was done to ameliorate ologopolistic markets and to provide for land affordability. By the early 1990s the commissions began to address the challenges presented by the environmental movement. For example, VicUrban joined with a local City Council (Broadmeadows) and the local newspaper to support the greening of the area through a large scale tree planting program; actively promoting a 'smart block' program aimed at supporting solar efficiency in new housing design; and developed 'an energy efficient demonstration village' on one of the estates [3]. By 1993 it was cooperating with the Australian Conservation Foundation to build a 'green home' which was built from environmentally friendly materials and was designed to consume less water, energy and resources [4, p.34]. This focus on environmental performance of dwellings continued and in 2003 led to the completion of the EcoHome by Metricon, a volume builder, on land developed by VicUrban. This has become the focus of an action research project led by RMIT and Deakin Universities in partnership with eight industry partners [5].

VicUrban is now implementing these objectives at the scale of the MPC. This means that for VicUrban environmental sustainability now extends to energy and water efficiency of dwellings, and the provision of public transport. They are also addressing building and material use with the objective of improving indoor environmental quality, choice of building materials aimed at reducing environmental harm, and reducing building waste. Attention is also given to reducing the impact on the local ecosystem and maintaining biodiversity.

\section{Chartering for performance}

The Sustainability Charter is most simply described as a system for guiding the planning and assessing development outcomes for each VicUrban project against measurable criteria. VicUrban [6, p.5] states

The Charter has been designed to ensure that VicUrban's new urban communities and strategic development activities are underpinned by measurable principles of economic, environmental and social sustainability.

The genesis of the Sustainability Charter was in the Melbourne Docklands Ecological Sustainable Development (ESD) Guide. This guide sets out principles and detailed building performance criteria which are used in working with developers to guide them in incorporating ESD principles in their developments. Developed, and used originally by the Docklands Authority, it continues to be used to set a minimum level of ESD performance required for development plan approval.

In summary the Sustainability Charter is structured around five headline corporate objectives: commercial success; community wellbeing; environment; urban design excellence; and housing affordability. Each of these is then extended by specifying Priorities, Objectives, and Performance Measures. For 
example, Commercial Success is expressed through three priorities, Financial Appraisal, Benefits Optimisation and Risk Assessment and Management. Objectives are then set for each Priority. There may be more than one objective per priority. Performance measures are then set and, again, there can be more than one performance measure per objective. Performance assessment is done by scoring against each performance measure up to a specified maximum score. There are two types of performance measures. There are those that must be scored, described as mandatory. The second group is discretionary and is scored only if selected as a part of the mix of features for the particular project. Each headline corporate objective has a potential maximum score of 100 and the VicUrban scoring 'rule' requires a minimum of 60 out of 100.

In addition, under each headline corporate objective, except for 'Commercial success' there is provision for an additional maximum score of 10 for an 'Industry Advance Factor'. This is there to encourage the development and incorporation of innovation. Potentially, each headline corporate objective area could achieve 110, other than the 'Commercial success' area.

Of course judgments have been made in the development of the Sustainability Charter about the relative importance of the Priorities, Objectives and performance measures at the outset. This is evident in both the maximum score setting for each performance measure and whether it is mandatory or discretionary. It is also evident in the number of priorities, objectives and performance measures set for each of the five headline corporate objective areas. An indication of this is evident in the following table.

Table 1: VicUrban Sustainability Charter count of Priorities, Objectives and Performance Measures.

\begin{tabular}{|l|c|c|c|c|}
\hline $\begin{array}{l}\text { Headline core } \\
\text { objective }\end{array}$ & $\begin{array}{c}\text { No of } \\
\text { Priorities }\end{array}$ & $\begin{array}{c}\text { No of } \\
\text { Objectives }\end{array}$ & $\begin{array}{c}\text { No of } \\
\text { Performance } \\
\text { Measures }\end{array}$ & $\begin{array}{c}\text { Mandatory } \\
\text { performance } \\
\text { measures (\%) }\end{array}$ \\
\hline Commercial success & 3 & 4 & 9 & 78 \\
\hline Community well-being & 5 & 11 & 20 & 0 \\
\hline Environment & 8 & 29 & 38 & 29 \\
\hline $\begin{array}{l}\text { Urban design } \\
\text { excellence }\end{array}$ & 9 & 9 & 39 & 15 \\
\hline Housing affordability & 4 & 6 & 10 & 10 \\
\hline
\end{tabular}

The following observations can be made about the structuring of the draft Sustainability Charter from this counting of Priorities, Objectives and Performance Measures:

- The assessment of 'Commercial success' is very precisely specified and there is little discretion over which Performance measures are used.

- The assessment of 'Community well-being' is specified using 20 Performance Measures but there are no mandatory measures. In other words, there is maximum flexibility in how the required score of 60 points is achieved. 
- The assessment of 'Environmental sustainability' has the second highest number (8) of Priorities the highest number of Objectives (29) and the second highest number (38) of 'Performance measures'. This area also has the second highest level of Performance measures that must be used.

- The assessment of 'Urban design excellence' has the highest number of Priorities and an Objective to match each Priority. This area also has the highest number of Performance Measures but a high degree of discretion over which ones must be used in project assessments.

- The assessment of 'Housing affordability' is undertaken using a small number of Priorities (4), Objectives (6) and Performance measures (10). Further, only one performance measure must be used in project assessments.

An additional important feature of the draft Sustainability Charter is that it is used to assess each project at five distinct stages: Project Vision, Project Goal Setting, Project Design, Project Delivery and Final Review. Within VicUrban the scoring process at each stage has broad organisational involvement. Assessments are made by VicUrban project teams with input from experts with particular expertise in each of the headline corporate objective areas. Further, continuous Project Quarterly Reports, using the measure tables, are submitted to the Project Control Group, Executive Board and Board. This enables the development of a cumulative picture of how each project is improving or declining in performance.

\section{Contributing to increased sustainability}

In this section we return to assess, in the light of the draft Sustainability Charter, how VicUrban is responding to the policy challenge of environmental impact of new suburban development.

\subsection{Environmental impact of low density suburban development}

VicUrban's commitment to improving the environmental sustainability of suburban development is expressed largely in the priorities, objectives, and performance measures of the 'Environment' and 'Urban design excellence' sections of the draft Sustainability Charter. These sections, as noted in Table 1, are the most detailed of the five sections. Also Section 1 'Commercial Success' contains a measure with significant potential for fuller consideration of urban infrastructure environmental costs and benefits.

This level of detail is, perhaps, not surprising for two reasons. First, many of the core objectives have characteristics where attainment is most easily assessed using detailed performance measures. Second, these detailed measures are being introduced into an industry long used to detailed specification of services and products. It is an industry with many specialised firms providing professional and delivery services [7]. 
Table 2: Typical land development industry professional and delivery services firms.

\begin{tabular}{|lll|}
\hline Developer & Professional Services & \multicolumn{1}{c|}{ Delivery Services } \\
\hline Site & Engineering Civic & Civic Construction Roads \& \\
identification/Acquisi & Hydraulic Traffic & paths Drainage Sewerage \\
tion Project & Surveying Urban design & Utilities installation Gas \\
management Sales & / Master planning & Water Telecommunications \\
Marketing & Landscape design & Electricity Demolition \& \\
Administration & Statutory planning & clearing Earthworks \\
Finance & Strategic planning & Excavations Construction \\
& Market research & management Land \\
& Valuations Legal & decontamination Land \\
& Sustainable development & rehabilitation/revegetation \\
& Heritage/archaeologist & Landscaping \\
& Environmental science & \\
& Sales, marketing, & \\
& communication & \\
\hline
\end{tabular}

Source: Charter Keck Cramer [7].

As Table 2 shows this industry has approximately forty different services or types of firms. In addition, there are builders who build dwellings on the estates created by the developers. In this type of organisational environment, exact and extensive specification has become the normal way of controlling quality and costs from design to completion. Hence, firms in the land development and building industries are familiar with responding to, and generating, detailed specifications.

The eight priority areas of the 'Environment' section are energy, water, transport, indoor environmental quality, materials, waste, landscape, and atmosphere. They all contain highly specified performance measures that VicUrban, as the project initiator, must communicate to the on-site tradesperson through the contracting and supervisory process all the way through. These priority areas are broadly of three types.

The first aims to lower the energy and water use of households who will live in the dwellings. For example, under the Water/Potable Water Conservation objective there is a mandatory performance measure requiring that 'total consumption be modelled $\leq 160$ litres per person per day in residential development' by addressing measures including water efficient appliances, rain water harvesting, grey water harvesting and dual supply pipe. Because of the professional and delivery service nature of the industry this specification of performance will affect the work of many professionals, including engineers, urban designers, architects and landscape designers, and delivery service providers, including the utilities, excavators, landscapers and plumbers. Another even more specific energy performance measure, although not mandatory, specifies the wattage and type of globe to be used for different types of lighting throughout the residence. 
The second seeks to reduce the broader environmental impact of housing construction by implementing new building design and on-site systems. This is done by setting performance measures for the selection of building materials through each dwelling achieving ' 100 points from the VicUrban Eco Materials Selector'. This is a way of reducing the up-stream environmental impact of building materials use. It is also to be achieved through construction waste minimisation through ' $80 \%$ of construction and demolition waste to be recycled or reused'. This provision requires the on-site trades to change the way they work.

An indication of the new land developer/house builder dynamic that these requirements can establish is evident in the statement of the VicUrban Aurora Project Manager describing a briefing workshop for potential builders of Aurora housing [8]:

We had 200 people at our first workshop, who wanted to be involved, who had heard about the project. The ongoing feedback from them is that they see that this is the way the industry is headed, and this project allows them to put in the R\&D. Partnering with us allows them to use our resources, because we have attachments to the different agencies - to EcoRecycle, the Sustainable Energy Authority - to get their R\&D up and running. They see that this is the way the industry is going and are happy to be a part of it.

In particular, the statement suggests the development of new capacity within residential building firms that resulting from specifying more sustainable products and materials, new on-site requirements.

The third environmental priority area relates to VicUrban developments spatially to metropolitan Melbourne through a transport priority, by specifying performance measures covering spaces for bicycle storage and 'access to alternative transport'. This latter performance measure states that ' $80 \%$ of dwellings are located within two of the following: $800 \mathrm{~m}$ of a railway station, and $400 \mathrm{~m}$ of a tram stop, $400 \mathrm{~m}$ of a bus stop, and $400 \mathrm{~m}$ of a ferry terminal or other'. The drive for improved environmental performance weakens at this point because the Transport priority performance measures are not mandatory and, therefore, do not have to be scored. In other words, VicUrban does not have to consider the level of household connection to the public transport system. However, it has to be added that this is not a VicUrban failing but reflects a fundamental weakness in the broader metropolitan planning system. It is a system that has consistently failed for many decades to provide adequate public transport investment in outer metropolitan suburbs for all new development $[9,10]$.

Finally, there is the performance measure contained in the 'Commercial Success' which indicates that VicUrban is seeking to calculate how its developments contribute to the environmental performance of urban infrastructure networks. Under an objective of 'Optimising the benefits of the project' it includes a performance measure: 
Identify the external benefits of all significant initiatives (externalities) where the benefits are enjoyed by others and the cost potentially cannot be recovered. These may be environmental, social, economic, e.g. reduced need for a new dam, reduction by volume of waste flowing into the sea, job creation, visitors to Victoria etc.

The draft Sustainability Charter does extend the requirement for residential environmental performance beyond the 5-Star standard required of all Victorian house builders. Therefore, the dwellings on VicUrban estate will be built to a higher environmental standard and could become a new benchmark. They will also be better located in the suburban landscape. However, at least as importantly, the processes being used by VicUrban are contributing to expanding the capacity of the housing industry to build dwellings and neighbourhoods with higher environmental standards while at the same time reducing the environmental externalities of housing construction. The problem that remains, that will not be solved by a TBL instrument like the draft Sustainability Charter, is how new outer suburban suburbs will be connected to the broader metropolitan area through a public transport system that will provide households with a viable option to car transport.

\section{Conclusion}

VicUrban, the Victorian Government's land development agency, systematically uses the word sustainability as a wrap around term to describe its' operations. Its definition and approach to sustainability is most clearly set out in five headline corporate objectives: 'Commercial success', 'Community wellbeing', 'Environment', 'Urban design excellence' and 'Housing affordability'.

This paper has assessed this pursuit of sustainability against three key issues that have been a feature of outer suburban development since the 1960s. The first was the issue of housing and land affordability. This led to the establishment of state government owned land development agencies, including the Victorian Urban Land Council, supported by federal government in the early 1970s. VicUrban is a direct descendant of this initiative. Second, there was the problem of inadequate infrastructure and service as suburban development raced ahead of infrastructure and service provision. VicUrban, along with other private sector developers, have been pressured by state governments into providing more and more of the on-site infrastructure, paid for through developer contributions. Larger Master Planned Communities are an outcome of this planning response. Third, during the 1990s environmental issues have become more prominent; new requirements have been placed on developers and house builders. VicUrban has gone further than other developers in greening the development of its outer suburban estates.

Since 2004 VicUrban has adopted a triple bottom line methodology as a means for planning and assessing its outer suburban estate developments. The instrument they have developed to do this is the draft Sustainability Charter which sets outs priority areas, objectives and performance measures under each of the headline corporate objectives. The charter is used to assess each 
development at four distinct stages from the initial project planning through to project completion and these assessments are used by the organisation at a number of levels including the Board.

The paper concluded by describing the draft Sustainability Charter and analysed its provisions against the background of the three long term urban development issues. In the area of housing affordability the analysis showed that VicUrban is doing little to increase the supply of affordable housing for low income households experiencing severe housing affordability and housing stress. VicUrban largely supplies housing to moderate income households. This cannot change until there is change in state and federal government housing policy frameworks that set the parameters for VicUrban operations. Community service provision for new urban development has increasingly been provided for through developer contributions required by state governments. In Victoria the framework for these levies and the provision of infrastructure are DCPs. VicUrban operates like all other developers within the DCP framework. The charter contains detailed provisions for increasing the environmental sustainability of new areas. These provisions represent a significant extension of the provisions required by the new 5-Star provisions. Further, the processes being used by VicUrban to build new neighbourhoods using these new standards perhaps is setting a new standard for suburbs.

\section{References}

[1] Gleeson, B., Darbas, T. and Lawson, S. 2004, 'Governance, Sustainability and Recent Australian Metropolitan Strategies: A Socio-theoretic Analysis', Urban Policy and Research, Vol.22, No.4, pp.345-366.

[2] VicUrban 2005, 2005 VicUrban Annual Report, VicUrban, Melbourne

[3] Urban Land Authority 1993, Annual Report, Urban Land Authority, Melbourne,

[4] Urban Land Authority 1993, Annual Report, Urban Land Authority, Melbourne,

[5] Centre for Design 2005, Sustainable buildings: EcoHome, RMIT University, Melbourne, Accessed May 9, 2006, http://www.cfd.rmit.edu.au/programs/sustainable_buildings/ecohome

[6] VicUrban 2006, Sustainability Charter Making Our Communities Better (Draft),

[7] Charter Keck Cramer 2006, Residential Land Development industry in Victoria - Assessment of Economic Benefits, Urban Development Institute of Australian (Victoria), Melbourne,

[8] Jolic, A. 2004, Transcripts of Evidence, Inquiry into Sustainable Urban Design for New Communities in Outer Suburban Areas, Parliament of Victoria, Melbourne, http://www.parliament.vic.gov.au/osisdc/inquiries/sustainableurbandesign /transcr ipts.html

[9] Mees, P. 2000, A very public solution: transport in the dispersed city, Melbourne University Press, Melbourne. 
590 Sustainable Development and Planning III

[10] Frazzetto, M. 1999, 'Public Transport Decline in Melbourne', Urban Policy and Research, Vol.17, No.2, pp.131-144. 